東芝鶴芫病院放射線科

○蕗 利彦・木田勝美

東芝医療器事業部

青木久敏・芋川康夫

[目的]高感度システム, 特に希土類增感紙が使用さ れるようになってからフィルムの粒状性が問題となり， 撮影系システムによる画貿改善の試みが各所で取り上げ られている。我々はこれまでの撮影系システムの検討を 含めて感材処理で画質改善を検討し，好結果を得たので 報告する.

〔結果】各社の現像液高温 1.5 分処理, 低温 3.5 分 処理で比較をし，画賀の荒れ具合いを検討した結果 D社 現像液の $25^{\circ} \mathrm{C}, 3.5$ 分処理汃仕上りのよいX線写真を得 た。日常業務の中で定性的ではあるが被曝軽減を画質改 善の武みを進歩する感材システムの中から上手に使いと なすととす重要な業務だと思われる。

\section{9. 自動現像機の現像系における銀泥えの対策}

金沢大学㗨学部附属病院放射線部

○山本喜代志・北野，保

[目的と方法】 film size 別補充や cine 系好理液再生 使用は実用化されたが銀泥には言及していない。よって 現像液や同槽壁銀泥を光学顕微鏡で観察し，廃㲤自現機 の現像槽之循環系液中固形成分分析を小西六工場儿依頼 する。

〔結果と結論〕液中銀量比には大差なく，固形成分は 循環系試料が，1/3なのに約 7.5 倍含有す。現像槽壁や ラック附着物はゼラチンと銀粒子が分離集落し支持体片 を含み，液中ではゼラチン塊と銀粒子の集落に支持体片 が混在浮遊し，生 $\mathrm{film}$ 辺緑に支持体断裂部や乳刜層剝離 断裂像を㤠め, $35 \mathrm{~mm}$ film の辽縁像や現像液中6同樣 の現象で樹脂系繊維布を現像槽底部に敷くだけで励染軽 減し，現行 filter 位置の不合理性を示すすのである。

170. pHメータによる自現機現像液の連続測定について 泫賀医科大学医学部附属病院放射線部

○近藤康雄・本多達哉・雄川供行 小水 満 ·横田 豊

現像液はその化学性が変動し易くしかすそれが現在の 自現には表示する機構をすっていない，現像液痩労度測

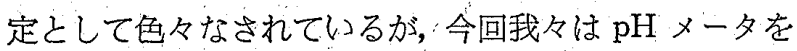
自現機に直結させ安定した現像液測定を試み,フィルム 黒化度と $\mathrm{pH}$ 值の関係について分析し疲学度測定の一手 段として連続的表示つまり自動管理の為の $\mathrm{pH}$ 測定につ いて検討を加え次のような結果を得た。 $\mathrm{pH}$ 值, フィル 么黒化度，コントラストの相関をとっておき，定常使用
時の液疲学に対する黒化度低下，コントラストを一定に して㧍けばその範囲に $\mathrm{pH}$ 值の変動を抑える様に補充量 をコントロールすれば，安定した現像管理が，期待出来 る.

171. 増感紙を併用した口腔内フィルムパックの試作と その臨床的評価

東日本学園大学霜学部附属病院放射線部

○輪島隆博 ·田中 昭

現在齿科領域でのX線撮影はノースクリーンタイプデ ンタルフィルムが主体であり，その膨大な撮影件数と共 にその被曝線量も問題となるとしろである.市販品はす ベてノースクリーンタイプであるが，診断目的によって はある程度画質を犠牲にしても充分彰断可能なものが多 く，当然「画像の撰択」の必要性が出てしかるべきであ る.そこで我々は口腔内X線撮影に際し増感紙を併用し たフィルムパックを試作し臨床に応用した。結果は; 約 1/5〜1/250まで軽減可能であったが，1/5，1/10タイプ は従来のノースクリーンタイプと同等の性能をもち，ま た $1 / 30 ， 1 / 50$ タイプは解像度の要求度の比較的 低い症 例に対して有效であった。

\section{2. 新しシリーズ増感紙の特性と応用}

化成オプトニクス秼式会社

○鈴禾優二郎・四宫恵次・三浦典夫

写真特性及び面久性を向上した新Lシリーズ増感紙の 商品化を行ない，その特性と応用について報告した. $\mathrm{LH}$, LT では螢光体発光效率の向上乙増感紙構造の最適化に よって, 鮮鋭度を 2 本 $/ \mathrm{mm}$ で約 $10 \%, 3$ 本 $/ \mathrm{mm}$ で $15 \%$, 4 本 $/ \mathrm{mm}$ で $20 \%$ と高周波領域での $\mathrm{MTF}$ の向上を計っ た. $\mathrm{LF}$ では分散性の優れた超微粒子 $\mathrm{CaWO}_{4}$ 螢光体の 全面的採用によって粒状を改良した。更にいずれす保護 膜のポリエステル化，プラステック支持体の採用により， 化学的酎污染性の強化及び柔軟性, 表面平滑性の向上が. 可能となった。とれらの性能向上の効果は臨休上におい て屯顕著に現われ，特に LH-II は胸部領域まで問題な く使用できること成確認された。

173. ニュータイプグレネックスシステムの開発

富士写真フィルム株式会社

商品開発センター足柄研究所

○八木実・福岡孝義

〔目的]グレネックスシステムの一置の利用拡大と被 曝線㽬軽減のために，個々の性能を再検討しシステムと しての適性化をはかり，総合性能の向上をはかる。

[結論]

(1) 従来の高感度, 高鮮鋭度を維持し, 粒状性を大幅 